\title{
Homework: A Type of Abuse?
}

\author{
López-Méndez HA* and González-Rubio R \\ Former presidents of the Private Pediatrics Group of the School of Pediatrics of Jalisco, Mexico
}

Submission: September 23, 2017; Published: March 19, 2018

*Corresponding author: López-Méndez HA, Former presidents of the Private Pediatrics Group of the School of Pediatrics of Jalisco, Email: fer_31@hotmail.com

\section{Introduction}

"The evidence to justify homework for children is not only doubtful, it simply does not exist".

Homework is defined as the work assigned to students by their teachers and intended to be done at home, outside the classroom and the school day, with or without the help of others. In some countries it is used as a synonym for "duty or obligation," an implication that bears the name, for it is defined as that to which man is bound by religious precepts or by natural or positive laws, a name that may not be the most appropriate. Some teachers define homework as the activity to be performed outside the classroom and suitable for the preparation, practice or extension of school work.

Homework is a word of Arab origin and comes from the word Tariha that simply means task or work that must be done in a short time.

The debate over the usefulness of homework has existed since the late nineteenth century. As early as 1884 the British Medical Journal reported that psychiatrist James Crichton-Browne had testified in the British parliament; "I have found many pitiful examples of mental health disorders, brain diseases and even deaths in cases involving young children resulting from forced studies in the afternoon which bring about nervous excitement and loss of sleep that very often accompany these tasks." There were times when homework was widely favored and others where homework was completely eliminated because no evidence whatsoever was found to justify its use. Between 1899 and 1915, several districts in the United States published anti-homework regulations after a cross-check about this topic in California, where legislation was passed in 1901 abolishing homework in the first 8 years of Schooling and limiting it in secondary school. In 1948, also in the American Union, only 3 to 4 hours of homework per week were suggested in high school students. However, between the years 1940 and 1960, it was decided to reform the homework assignment, making it more extensive, creative and individualized. At the same time, specifically between 1949 and 1955, there was a progressive pro-intellectual movement that became an enthusiastic promoter of homework. Unrelated to the issue, on October 4, 1974, the world received what can be considered the most shocking news of the 20th Century; from Kazakhstan, Russia, for the first time in the history or our civilization, a device called Sputnik I, just slightly larger than a basketball, became the first artificial satellite created by mankind and placed in orbit around our planet. This was a strong blow to the United States of America and with Dwight David Eisenhower taking the lead; began a special race that brought about many changes to their society. One of them was to promote homework in a larger scale to compete against the youth of the Russian Counterpart they believed held an alleged cultural advantage. Here began one of the biggest mistakes in the history of teaching, the distorted approach of contaminating education with competition. From this moment on, education dealt with competition and without knowing, would be the beginning of conflicts. The day when one educates for cooperation and solidarity with others? That day education will be for peace as per the words of Maria Tecla Artemisia Montessori. During the 1960's the tendency of assigning more homework continued with parents demanding from the schools the ancient desire of academic excellence without taking into account the strengths, needs, gifts or dreams of each of their children. We can therefore summarize that in the first half of the 20th century, schools forgot about assigning homework but from the 1950's on, it again reignited with much enthusiasm where the assigning of homework became globalized in the last 20 years of the same century.

Homework is one of the educational activities that has generated the most controversy in the different educational sectors. There are no clear criteria regarding how, when, where and how much should be assigned. The controversy is still far from having a strong response, mainly on the degree of utility and its effects on learning. One must add to this the fact that new research on homework does not offer answers to the many questions that arise when recommending their use, nor do they point the way forward in the future. 
For some professionals, homework is discriminatory; all the weight of the assignment was designed for the typical middleclass family in an era that existed one hundred years ago. An era where father, mother, several children lived in a very determined hierarchical structure where the mother did not work and dedicated herself exclusively to the care of the children [1]. In reality, single-parent families or families where both parents work or have some disease or are illiterate or have another characteristic that makes them vulnerable are, at a disadvantage compared to those who have a context similar to the ones for which the homework was assigned. This difference is much greater when students live in disadvantaged socio-cultural environments [2]. The greatest worry is that the negative consequences of not doing the homework will fall on the students, not taking into account that they are not responsible for their circumstances. To clarify, the assignments are sent home in most cases, without the teachers taking into account the personal life of the students just as it was done a century ago. We do not change, we do not evolve, this sounds extremely unfair and without sense.

The rights of children are stipulated in the "Convention on the Rights of the Child" adopted as an international treaty on human rights on November 20, 1989. Throughout its 54 articles, it recognizes that children (Human Beings under 18 years of age) are individuals with the right to full physical, mental and social development. This convention establishes minimum obligations by which the signatory governments must comply. These are the rights to equality without distinction of race, religion, language, nationality or sex, the right to leisure and recreation, play and recreational activities within their age group and the right to participate freely in cultural life and the arts (article 31). All signatory countries must commit themselves to provide appropriate opportunities for the fulfillment of these mandates in Conditions of equality. If we remove the right to have time for recreational activities by forcing children to fulfill school duties, we are failing to comply with this elementary mandate. Perhaps we are removing the right to protection against some type of abuse. By being strict, having hours outside their school hours doing things they do not like that does not give them benefits, we fall into a clear act of Mistreatment. It is the obligation of the public authorities to promote the enjoyment of these rights. Failing to do so will cause them to fall into default, in breach of their oath to comply and enforcement of the laws. Let us not forget that the best interest of the child must be the guiding principle of those who have the responsibility for their education and guidance and this; is not negotiable. When we watch children play we realize how integral development is, Pediatrics and Child Psychology has always emphasized the importance of play for infants. Over two thousand years ago, the great philosophers Plato and Aristotle mentioned that children only have an obligation in their first years of life to play and learn music. With this, they concluded children would achieve optimal brain development. We now know that brain plasticity, which is the adaptive capacity of the nervous system to regenerate anatomically and functionally after being subjected to environmental, pathological or developmental influences, is achieved with adequate stimuli and occurs throughout life. So, it is never too late to try to develop it. One must remember that the brain changes physically, functionally and chemically forming new synapses and releasing multiple neurotransmitters improving what is already an acquired skill or established skill.

The brain is designed to be stimulated and challenged to be modified in response to experiences, to examine the environment and to solve problems. In ancient times, following the details for the human was imperative for survival. In infants the most important stimulus is play; it is their way of interacting with the environment and their best way of stimulating optimal neurological development. The worst damage we can do to a brain is to do things daily, repetitively, without paying attention to the details we see, hear or feel. If we leave a child without the play stimulus, we limit neural development. Why then with this physiological evidence are we moving away from nature and trying to change the natural order?

Playing is for the child, the time for spontaneity and authenticity, for creative imagination and fantasy playing by their own rules. The game is the motor of physical activity; it is a means of socialization, the externalizing of their emotions, feelings and creativity. It is from this game where the public speech of the child begins to become the internal language to self-direct their behavior and also their external language to discuss, negotiate, reach agreements and take initiatives. With toys it represents the reality and processes of abstraction. They use them as a tool and they provide moments of happiness, leisure and well-being. Toys are one of the best educational resources for their learning to play. We are primates that enjoy learning and playing and thinking carefully we are not so different, the important thing being how we implement them correctly.

Songs are part of the children's game, it entertains them, starts them in the music world, reinforces their attention and memory, expands their vocabulary, helps them discriminate sounds, tones, timbres, rhythms and helps them to coordinate the body. When the song is accompanied by dance, gestures or mimicking? The song also helps to socialize, to exteriorize emotions, to create habits such as the lullaby, which has been used for hundreds of years and is part of the cultural background of many individuals. It serves to learn things from everyday life such as numbers, colors, body parts, even to start with words from another language. We must encourage parents to give themselves time in their children's play. Sharing part of their leisure time through play is a pleasant and enriching experience for the whole family. Let us then try to understand why the theory that an activity should be left to the students to perform in their free time, is completely questionable because there are several beneficial and necessary activities for the student in their time out of school.

Some justifications for homework have been that they develop positive aspects such as self-discipline or responsibility. This has been negated by some researchers like Alfie Khon, who concludes 
that the task itself does not develop the positive aspects and instead only teaches others what to order. Another justification is that it increases the academic result but, this has not been demonstrated. There is no serious evidence that the academic performance of elementary students improved and only a minor improvement is accepted in the secondary schools $[3,4]$. What is also said that the task arouses interest in children, Crain showed that it is not only false, but that children see it as a punishment. For many it is the greatest extinguisher of childish curiosity. Some educators have argued for years that learning depends on the amount of time dedicated to this. Today we know that it is not due to quantitative changes that knowledge is optimized but with qualitative changes in how the students are involved in the learning process that determines the success. It is not the time they devote at home, it is the amount of quality time for learning that is optimized in the classroom.

The children have to show at home what they did in class and not show in class what they did at home.

We are faced with a topic of great importance for all students, a topic that many feel dubious, annoyed, frustrated, confused or disappointed and yet, we do not question the habit of continuing to assign homework and much less try to stop them despite not finding a clear and conclusive justification. It is difficult to change customs in places where commitment to duty is closer to religious dogma than to scientific hypothesis. When it is suggested that we support any policy that is in effect in our community, even one that may be harmful just to not cause controversy? It seems a deeply perverse and unjust advice in any context. The avoidance of talking about homework makes us accomplices to the damage it can produce in the students by depriving them of the wonderful time in the varied and important fields necessary for their development [5].

Let us dare to doubt the basic belief that duties are necessary and desirable. We should debate their value and if we are convinced that they do more harm than good, we should take a stand against them. We must convince ourselves that we can learn without having to hate what we study. Teachers should talk amongst themselves about the subject and not just take it for granted. They should also talk with parents and friends but importantly we should listen to the children and young people who have every right to comment on things they consider useful or detrimental and not limit them to obeying just because this subject is in the hands of adults. Instead, let us empathize with them and try to observe through their eyes what they are going through [6-9].

Let us raise our voice and emphasize that the evidence to justify homework in children is not only doubtful, it simply does not exist.

When the school's priorities are wrong, do not accept them. Let's understand that family, children and true learning come first. If the tasks persist for a myth, we owe it to our children, all children, to fight with all our forces to eradicate them and allow only procedures that are science-based and meaningful for all.
When we question the children that we see on a day-today basis in our pediatric offices and touch on the subject of homework, everyone agrees in one way or another on the same answers, "I do not like them," "I'd rather play than do them, "They do not do anything for me", "they make me argue with my mom", "she does them", "the teacher does not review them", "they are sent by teachers so they have something to grade", "by doing homework I stopped going to train", "I copy them from my classmates" and a long etc.

Many students participate in homework not because of the interest or enthusiasm they produce but rather for reasons such as the sense of responsibility, the desire to please or to avoid punishment. Of course these reasons are all negative and will relate to low levels of persistence, low learning, poor performance and greater risk of dropping out of school which is in direct violation of Article 28 of the Convention on the Rights of Children, which states that we must adopt measures to encourage regular attendance at schools and reduce the dropout rates.

In Mexico, homework is very common in the education system. Has there actually been serious debates regarding homework before assigning said task in the terms of objectives, nature, characteristics, duration and revision of such? Surely not; by which the assigning of homework is arbitrary, without any association to learning and even less with the development of the mind. What is the amount of time that should be dedicated to homework? Is it well studied? The teacher usually decides and assigns homework arbitrarily and surely does not know the family environment of each child to be able to corroborate if the amount of time it will take the child to do the homework assignment is prudent including, the time it will take the parents. Is it right to get involved in family customs by taking valuable time away so it can be dedicated to homework? These assignments distance the students from their families. Young people naturally resist doing homework $[10,11]$. For this reason the teachers ask the parents to take part in this matter and in doing so, turn them without their knowing, into policing their children so they abide by the orders emanated in the classroom with the obvious intra-familiar conflicts that will repeat on a day to day basis. Schools should encourage involvement of families in other ways, other than just forcing them to help their children perform tasks that they alone cannot do. Imagine a mother who when asked to help her child complete a homework assignment at home because it was not completed at school asks the teacher; can you come over and do my laundry and chores I do at home since I was not able to do them because I had to help my child with his homework that should have been done in the classroom?

There is no regulation as to the amount of time that should be assigned to homework and school work as a whole. The General Law of Public Education refers only to the Calendar School Year where the number of class days is established but not the number of out of school days, different from what the Labor Laws establish as the maximum hours of work. Maybe it would be advisable to establish by law the number of out of school days? Would it 
be correct to put the subject of homework in the agenda of the national educational debate while remembering that students are about $25 \%$ of our population but, $100 \%$ of our future?

The stress that the school provokes in students has always been linked to two activities in particular, one is the realization of exams and the other is the homework. In some schools students spend up to 3.1 hours every afternoon on homework, so it is easy to understand the reason why they have to abandon other activities that amuse them, because they say they feel tired and this is the cause of their transition to a sedentary lifestyle.

With the forced increase in stress demonstrated in recent investigations and all its consequences, mainly arterial hypertension and diabetes that every day we are seeing more and more at a younger age, we are going to be the cause of the collapse of the health services in the whole world in a very short time. These reasons alone should be more than enough to get the children out of their homes in the afternoons and have then lead an active lifestyle and forget about homework. We cannot simply with ideas modify the 24 hours of each day. Let us then count the hours of class at school, hours of homework, time to eat, time for personal hygiene, time for rest, time for fun, time for socialization, time to read and time to sleep. Let us then eliminate the activities that we can do without and allow the students to realize other more important things, mainly the life that goes with being a child.

Recent studies have shown that countries that assign short assignments or who even do not assign them have better school achievement. "The best teaching is the one that uses the least amount of words necessary for the task".

Whenever homework overwhelms social experience, outdoor recreational time, creative activities and bedtime, not only is it not serving the children's basic needs but is also causing them damage that will most likely be permanent [12].

Children have been sleeping less with the passage of time at a slow rate of about 40 seconds per year. Nowadays our children sleep about an hour less than their great-grandparents did when they were their age and one of the causes of this decrease in sleep time is related to extracurricular activities.

Excessive homework can negatively affect not only the child but also the family as a whole. Tired children who protest and cry with desperate parents who pressure them, shout at them or punish them. Those hours in the afternoon that instead of being to play, talk, do things together, to read to them or ask them to read, learn music, learn crafts, teach them to say hello, to say thanks, to be clean, to be honest, to not curse, to respect others, to be supportive, to share, to not lie, to eat with their mouths closed, all things that are taught at home, things that are useful, transcendent and pleasant, but by one bad decision, they are replaced by senseless homework [13-15].

Let us propose then to our elected officials, school leaders, teachers, physicians, psychologists, nutritionists, parents and students that they come together to reflect and to do research to determine how homework benefits students and, if necessary, adopt them but clearly set the parameters that they should have and if it is determined that they are not justified, have the courage to eradicate them completely.

If at a given moment and with a solid basis we conclude that homework should be assigned in schools because in doing so the contexts learned in school are extended beyond the school grounds, then we need to put some minimum requirements that must be fulfilled; that they must be planned and never routine or improvised; that they do not overburden the daily activities of the student; that they be gradual in quantity and difficulty, that compels the students to produce, not to reproduce, that they never be used as punishment for the student or for the parents, that they not only help students to take care of themselves with clear and precise instructions but also encourage students to do them with pleasure, to be reviewed, to be corrected and result in positive feedback.

We must take into account that if the teacher complies with these bases, they will have to devote a lot of their regular time to this activity because, if you spend 5 minutes with each student and multiply by that by all the students? That will add up to several hours a week for this purpose and more than a hundred teaching hours a year. It is very likely that some teachers will not agree to dedicate this time to them; so one should think twice before advocating this routine. Teachers have one of the most important jobs to which a human being can aspire but usually underpaid, exhausting and with the obligation to perform their trade in a system without many options for change or rights. Let us help them do their work more efficient and rewarding.

With this we come to the conclusion that we must question any activity that is done out of habit and has no recognized value as is the case of homework. We must of course question it with scientific knowledge, which is well documented, and never with foolish or particular interests; by observations done by other entities and the results they have had and the most important being our learning to listen at those trying to change by good faith the erroneous paradigms that are rooted in generations of our society. Let us not automatically disqualify them simply because they want to make certain changes without first deeply analyzing their proposals, particularly speaking about the professionals who are committed to the children and their environment.

Let us continue to investigate this topic and other topics that have to do with the well-being of children; let us make it a public discussion so as to reach those responsible in our government who can make decisions and convince them that changes are needed to improve the quality, level and efficiency of education and of course get us to the ultimate goal that is and always will be, the good development and happiness of the child.

\section{References}

1. Dudley-Marling C (2003) How school troubles come home: The impact of homework on families of struggling learners. Current Issues in Education, 6(4): 1-11. 
2. Kralovec, Etta, John, Buell (2000) The End of Homework: How Homework Disrupts Families, Overburdens Children, and Limits Learning. Beacon Press, Boston, Mass, pp. 1-144.

3. Cooper, Harris M (2001) The battle over homework. Corwin Press, Thousand Oaks, California.

4. Bennett, Sara, Kalish N (2006) The case against homework: how homework is hurting our children and what we can do about it. New York, USA

5. Bennett, Sara, Kalish N (2007) The case against homework: how homework is hurting our children and what we can do about it. Three Rivers Press, New York, USA.

6. Aggio D, Smith L, Fisher A, Hamer M (2016) Context-specific associations of physical activity and sedentary behavior with cognition in children. Am J Epidemiol 183(12):1075-1082.

7. Harris Cooper, Jorgianne CR, Erika A Patall (2006) Does Homework Improve Academic Achievement? A Synthesis of Research, 1987 -2003. Review of Educational Research 76(1): 1-62.

8. cooper, harris, lindsay, james j, nye et al. (1998) relationships among attitudes about homework, amount of homework assigned and completed, and student achievement. Journal of Educational Psychology 90(1): 70-83.

9. Jussila, Anne-Mari, Vasankari, Tommi, Paronen, et al. (2015) KIDS OUT! Protocol of a brief school-based intervention to promote physical activity and to reduce screen time in a sub-cohort of Finnish eighth graders. BMC Public Health 15(1): 634.

10. Kumanika S, Jeffery RW, Morabia A, Ritenbaugh C, Antipatis VJ (2002) Obesity prevention: the case for action. Int J Obes Relat Metab Disord 26(3):425-436.

11. Lau DC, Douketis JD, Morrison KM, Irene M. Hramiak, Arya SM (2007) 2006 Canadian clinical practice guidelines on the management and prevention of obesity in adults and children (summary). CMAJ 176(8): S1-S13.

12. Michaud I, Chaput JP, O’Loughlin J, Tremblay A, Mathieu ME (2015) Long duration of stressful homework as a potential obesogenic factor in children: A Quality study. 23(4): 815-822.

13. Rushovich BR, Voorhees CC, Davis CE, Neumark-Sztainer D, Pfeiffer KA, et al. (2006) The relationship between unsupervised time after school and physical activity in adolescent girls. Int J Behav Nutr Phys Act 31(3): 1-9.

14. Schwartz DH, Leonard G, Perron M, Richer L, Syme C, et al. (2013) Visceral fat is associated with lower executive functioning in adolescents. Int J Obes (Lond) 37(10): 1336-1343.

15. Cathy Vatterott (2003) There's something wrong with homework. 64 1-3.

\section{Your next submission with Juniper Publishers will reach you the below assets}

- Quality Editorial service

- Swift Peer Review

- Reprints availability

- E-prints Service

- Manuscript Podcast for convenient understanding

- Global attainment for your research

- Manuscript accessibility in different formats

( Pdf, E-pub, Full Text, Audio)

- Unceasing customer service

Track the below URL for one-step submission https://juniperpublishers.com/online-submission.php 